\title{
Theological dialogue towards ethical restoration in a homophobia-riddled society
}

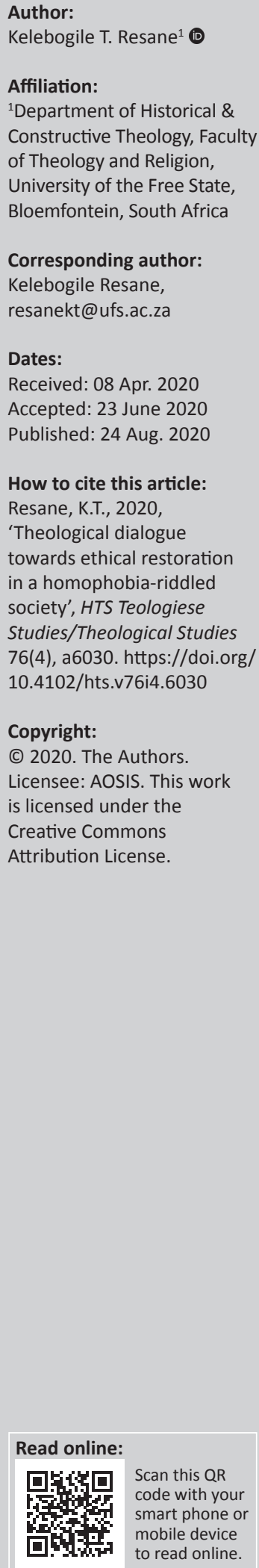

Homosexuality and homophobia in South Africa exist side by side. Homophobia is very common in communities and churches. Biblical texts, traditional cultures and politics partner to dismiss, discredit or disqualify homosexuality, but historians and anthropologists have evidence that homosexuality has been around within African cultures for many ages. Christians are divided into two camps. There are those who openly oppose gay rights with citations from biblical texts, claiming that homosexuality is forbidden by God. Others claim that this is poor biblical scholarship and a cultural bias read into the Bible. To these, the Bible says nothing about homosexuality as an innate dimension of personality; as a sexual orientation, it was not understood in biblical times. Despite a progressive constitution and affirming legislation, sexual and gender minorities experience discrimination in South Africa. The church expresses homophobic tendencies by excluding homosexual people from the sacraments, liturgy and ordination. Theology is invited to embark on a journey of dialogue with communities and homosexual people in order for it to be meaningful and relevant and contribute towards social, political and economic empowerment. Through dialogue with the homophobic community, theology can journey out of the continuous hermeneutic circle spanning biblical text, dogmatic traditions and the present, ever-changing historical context. This journey is taken, applying the ethics of faith, hope and love.

Contribution: The article invites further research on theological grounds for exclusion of same-sex orientation people from ecclesial rights such as ordinances, liturgy, confessions and ordination.

Keywords: homosexuality; homophobia; dialogue; same-sex orientation; church; theology.

\section{Introduction}

The intention of this article is to give neither the theological nor psychological reality of homosexuality, nor to argue for or against it. There is abundant literature on this subject. The argument here is that, whether theologically correct or incorrect, there is an elephant in the room. Homosexuality is vogue la galère! - a real inevitability. The concern here is homophobia. The community - religious or civil - is encouraged to create a space for dialogue in order to learn and understand the matter at hand, especially in the church. Instead of ascending the bema to judge people of same-sex orientation, and exclude them from ecclesiastical processes, there should be some ethics of acceptance, love, embrace and inclusion. These are summarised in three New Testament words: faith, hope and love. The attitudes and assessments of any ethical query should be governed through these three ontologies.

\section{Africa and homosexuality}

Generally, a homosexual person is anyone, male or female, who engages in sexual relations with members of the same sex or who desires to do so. It is an affectional attraction to, or active sexual relation with, a person of the same sex. Homophobia is a dislike of or prejudice against homosexual people. It is antipathy and hatred by heterosexual people towards non-heterosexual people. There is a general belief that African people are deeply homophobic and unaccepting of gender diversities. African homophobia has been attributed to European colonisation in the literature, in both theological and secular studies. This is contrary to literature that shows that homosexuality and same-sex relations can be proved historically among current and various Southern African tribes. There is an indication that in the 18th century, the Khoikhoi people had some linguistic characters such as koetsire as a reference to a man who is sexually receptive to another man. There is also soregus, referring to same-sex masturbation practised among friends. ${ }^{1}$ Amara Das Wilhelm (2004:230) makes reference to AmaZulu (inkotshane), Basotho (boukonchana), Mampondo (tinkonkana) and Xitsonga (nkhonsthana) terms that refer to 'boy-wives', who typically 1.https://historycollection.co/these-time-periods-in-history-surprisingly-accepted-and-celebrated-homosexuality/14/ (viewed 29 March 2020 ). 
dressed as women, sometimes wearing fake breasts. They performed chores associated with women, such as cooking and fetching water and firewood. They engaged in intercrural sex with their older husbands, called numa in isiZulu and Sesotho and nima in isiMpondo and Xitsonga. These boys were not allowed to grow beards and not even allowed to ejaculate. After reaching manhood, they were released and given some freedom to take their own inkotshane by choice (Murray \& Roscoe 2019).

Bernadine (2014) agrees with Epprecht (2003:3) that these relationships were also known as 'mine marriages', as they were commonly practised by miners until the 1950s. They are commonly discussed as homosexual relationships, though sometimes the boy-wives are discussed in the context of transgender experiences (Bolich 2007:250; Zabus \& Coad 2013:163).

The Batswana and the amaNdebele are also documented as having a tradition of acceptance or indifference towards homosexual acts. At a day-long meeting for 25 local chiefs (dikgosi), hosted by the anti-acquired immune deficiency syndrome (AIDS) human rights organisation BONELA (the Botswana Network on Ethics, Law and HIV/AIDS), gay men and chiefs shared their understandings and experiences. The chiefs said that homosexuality has always been part of local society, as is clear from the existence of a word for it - matanyola - in the local Setswana language, which is spoken by about 4.5 million people in Botswana and South Africa. ${ }^{2}$

It is also noted that the amaNdebele and the amaZulu warriors would have intercrural sex. Effeminate men in Ndebele society would often become healers and spiritual leaders (Mabvurira et al. 2012:219). In these societies, homosexuality was not viewed as the antithesis of heterosexuality. There was widespread liberty to move between the two and engage in sexual activity with both men and women (Long, Brown \& Cooper 2003). Homosexuality was criminalised under colonial law as unnatural, and homosexual acts were deemed crimes against nature (Kuloba 2016:25).

\section{South Africa and homosexuality}

On 30 November 2006, a significant shift was marked in the South African constitutional history. On that day, South Africa became one of the few countries in the world to legalise same-sex marriages (Civil Union Act). This legislation offered lesbian, gay, bisexual, transgender and queer (LGBTQ+) people freedom to enjoy constitutional and statutory protections from discrimination in employment, provision of goods and services and many other areas. Condemnation and abhorrence of the orientation in the past was now replaced with civil rights, making South Africa one of the most liberal countries in the world. Lesbian, gay, bisexual and transgender groups still resist this act because it gives churches the freedom to refuse to marry them and limits the right to protection from hostile communities.

2.https://76crimes.com/2013/07/26/botswana/ (viewed 03 April 2020)
There is also a clause in the Civil Union Act that allows civil servants to refuse to solemnise civil unions if they object to same-sex relationships on the grounds of their 'conscience, religion or belief'. In a country that is religious, this presents a very real obstacle for same-sex couples who want to marry. This is quantified by the fact that LGBTQ+ South Africans, particularly in rural and township areas, continue to face challenges, including homophobic violence, particularly corrective rape.

For the first time, there is scientifically valid, nationally representative data to inform social dialogue and advocacy, public policies and academic debate. Progressive Prudes, ${ }^{3}$ one of the first surveys conducted on the 'attitudes towards homosexuality and gender non-conformity in South Africa', noted that:

- $51 \%$ believe that gay people should have the same human rights

- $72 \%$ feel that same-sex activity is morally wrong (amazingly!)

- $55 \%$ (half of the population) say they will 'accept' a gay family member

- $27 \%$ report having a friend or family member whom they know is homosexual

- $44 \%$ of the queer community reportedly experience verbal and physical and/or sexual discrimination in their everyday lives because of their sexual orientation, and sensitive issues are often remarkably under-reported.

Despite a progressive constitution and affirming legislation, sexual and gender minorities experience discrimination in South Africa. This reflects the ongoing impact of heteronormativity, 'culture' arguments and violence in suppressing non-normative sexual and gender identities. Christians do not intentionally choose to be homophobic; misinformation and lack of information regarding homosexuality are the main contributors to this ignorance.

Homophobia is a weapon for sexism, and it is understood through the lens of heterosexism. It is through gender roles that assumptions about what men and women should and should not do are made (Msibi 2012:525). Homophobia and sexism are direct manifestations of patriarchy. In conservative South African contexts, it is still seen as wrong for women to wear pants, as these garments are 'meant for men'. This practice is mostly upheld in conservative churches and cultural celebrations.

Another way that homophobia is used to maintain sexism in place is violence. Violence is used to enforce and regulate sexualities and in turn works to maintain patriarchy and heteronormativity (Msibi 2012:526).

The tension between homosexuality and religion and/or culture is another component that heightens homophobia.

3. http://theotherfoundation org/progressive-prudes/. The Other Foundation works to change the views, practices and institutions that prevent pople in southern Africa change the views, practices and institutions that prevent people in southern Africa from being able to be who they are or love who they love. Their objective is to gathe support for those who are working to protect and advance the rights, well-being and social inclusion of people of all sexual orientations and gender identities - and they give support in a smart way that helps groups to work better for lasting change. 
Butler and Astbury (2005:129) note this point in their research on homosexuality in South Africa. They observe that '[a]nti-gay sentiment is compounded in South Africa by a strong patriarchal Christian ethic that views same-sex sexual encounters as sinful and wrong'. Msibi (2012:527) notes that in this context, reactions against homosexual rights are seen, for many, as upholding religious beliefs and therefore something to be proud of and actively encouraged.

The data regarding these perceptions are in line with the data regarding the lived experiences of LGBTQ+ people throughout the country. So, with the social challenges on the ground in South Africa, homophobia is deeply rooted and situated in the religious and cultural conscience.

The negative conscience is enhanced or even complicated by three negatives (mores, colonial religion and apartheid) as well as by a positive: the human rights movement that contributed to the abolition of apartheid.

\section{Homophobia in the church}

Theologians and ecclesiastical communities tend to openly oppose gay rights with citations from biblical texts.

A reading of the Bible regarding human sexuality should never take place without reading texts in the historical and cultural context (Kuloba 2016:8). A high percentage of the church is consonant with the fact that homosexuality is condemned throughout scripture. In appealing to some Old Testament texts, biblical scholarship highlights the word used in many of these texts - 'abomination' - which generally translated means 'disapproval'. Leviticus 18 uses the term five times in reference to the sins most hated by God. Its Hebrew word, tô'ébāh, comes from the root meaning 'to hate' or 'to abhor'. An abomination is literally something detestable and hated by God (Wenham 1979:259). In a real sense, according to this condemnatory stance, ' $[t]$ he Levitical purity code describes homosexual acts as "something revolting", clearly showing the purity basis of the prohibition' (Vardy 1997:205). Theological debates continue to express that same-sex desires and same-sex orientation are part of the broken and disordered human sexuality owing to God's subjection of the created order to futility because of human sin.

Some New Testament scholars also make their mark towards abhorrence of homosexuality. They escalate some Old Testament scholars' belief that homosexuality among men $(\operatorname{Rm~} 1: 27)$ 'is further evidence of inversion of the created order' (Johnson 1979:36). They believe that although those caught up in this kind of sin need compassion, as any other sinner, it must be pointed out to them that it is a wrong practice and that its increasing practice in society is evidence of humankind's apostasy from the truth of God. These Bible scholars perceive homosexuality as a danger to the family order; therefore, it should be condemned and replaced with the defence of marriage as divinely ordained by God. Throughout the colonial era, for the church, homosexuality was 'the peccatum non nominandum inter Christianos - the sin not even to be mentioned among Christians' (Crompton 2003:1). This led to the church generally believing that homosexuality was ungodly and sinful (West 2017:116). Reading the biblical narratives of Sodom and Gomorrah, together with other biblical texts, combined with African patriarchal cultures:

[S]erves to amplify the imagery of homosexuality as a heavily punishable offence, and reifies the sanctity of the heteronormativity of human sexuality as the natural and godly way. (Kuloba 2016:27)

Some Christians argue that homosexual relationships are proper expressions of human love, whereas others stress that the Bible and tradition condemn such practices (Cook 1990:15). The former insist that claiming that homosexuality is 'forbidden' by God is poor biblical scholarship and a cultural bias read into the Bible. They argue that older versions of the Bible hardly use the words 'homosexual' or 'homosexuality'. For these exegetes, the Bible says nothing about 'homosexuality' as an innate dimension of personality because sexual orientation was not understood in biblical times. The argument is also enhanced by the fact that Bible commentaries published before 1990 hardly make any reference to the word 'homosexuality'. They continue to claim that there are references in the Bible to same-gender sexual behaviour such as that of David and Jonathan. However, what is condemned in these passages is the violence, idolatry and exploitation related to the behaviour, not the same-gender nature of the behaviour. There are references in the Bible to different-gender sexual behaviour that are just as condemning for the same reasons. However, no one claims that the condemnation is because the behaviour was between a man and a woman. This second claim is found both inter-religiously and extra-religiously. It is both inside and outside the church.

There is homophobia in the church. The majority of Christians believe that being homosexual and Christian at the same time is antithetical (Rodriguez 2010:26). The predominant interpretation of biblical scripture is omnipresent in African churches and seems to create limited space for clergy and the community to be open and accepting of its gay brothers and sisters. The limited space for acceptance in the Black church manifests itself in messages of intolerance (Clarke 2011:89). The rationale behind this is disputably a literalist text exegesis. The literalists make up the majority of the clergy in the Protestant faith and therefore exert much influence in hermeneutical understanding of the scriptures. Nel (2019) points out:

They are interested in the interpretation of authoritative texts and synthesising their analysis of these texts in a one-way direction from the text to the current reader. (p. 516)

The same notion leads to the conclusion that these literalists 'frame it [homosexuality] as a sin, a sickness, an aberration, a handicap, or something like that' (Ganzevoort, Van der Lan \& Olsman 2011:213). South African Christianity is at a crossroads regarding homosexuality. People of my 
generation who were privileged to study for pastoral ministry were never equipped to deal with this issue. In the 1980s, homosexuality or homophobia was unheard of within evangelical circles. Pastoral studies, including counselling, at the time never conscientised or equipped us for this current challenge. The fact remains that homosexuality has become a divisive issue in many religious communities. Partly because of that, individuals growing up in such a community and experiencing same-sex attraction need to negotiate the messages about homosexuality with their own experiences (Ganzevoort et al. 2011:89).

\section{Homophobia in communities}

Socioculturally, same-sex relationships cannot be anthropologically annulled or reprieved, for 'politically motivated and religiously sanctioned homophobia is a new development in Africa's sociopolitical history' (Kaoma 2015:10). South African society embraces the heteronormative values of Christianity; hence, it is functionally impossible for gay and lesbian people to be Christians (Garner \& Worsnip 2001:205-230). Silence, passivism and phobia cannot be left unattended. Dube (2004) is correct that there should be some intentional choice:

$[T]$ o encounter imperialist domination by embarking on a critical practice that seeks to understand, expose, undermine, and arrest the imperialist forces of oppression and exploitation. (pp. 235-236)

South Africa is a traditional and multicultural society, still wading in murky water to locate its identity in the community of the nations. South African nationals are limping in transition:

$[T]$ ransitioning between two cultural worlds that shape our sense of what is real: the sacred where the physical is excluded and the secular where the spiritual is excluded. (O'Gorman 2016:430)

The colonial biases and bigotries against homosexuality within African historical-anthropological narratives bred homophobia in such a way that it is deeply entrenched in society, where gay people are subjected to inhuman treatments. When people do not know their histories, they suffer at the hands of the perpetrators of unjust systems. Laird (1998) is correct:

[I] f we do not learn about our own cultural selves and that culture of the other, it will be difficult to move beyond our own cultural lenses and biases when we encounter practices that we do not understand or find distasteful; we will not be able to ask the questions that help surface subtle ethnic, gender, or sexuality meanings; and we may not see or hear such meanings when they are right there in front of us. Our own cultural narratives help us to organize our thinking and anchor our lives, but they can also blind us to the familiar and unrecognizable and they can foster injustices. (p. 22)

\section{Bones of contention: Sacraments and liturgy}

The church struggles with homosexual people in the areas of sacraments and the liturgy. There are several questions at hand: 'Should a minister/pastor conduct weddings for gay people?' 'Should gay people be allowed to participate in Holy Communion?' ‘Should gay people be baptised?' ‘What about ordination or credentialing into the ministry?' Theological input is necessary for these questions to be answered. It is a common knowledge that the canon of scripture, using all the necessary critical historical interpretative means available, is the church's final arbiter and judge. Ecclesiastically thinking, the sacraments of baptism and the Eucharist entail joining believers to the sacrifice of Christ in total self-giving. This self-giving goes far beyond human comprehension. It means surrendering one's individualism whereby one becomes a member of the one body in humility and service (Bradshaw 1992:46). No one exists as a Christian purely individually. The individual is in the church - not submerged by the church but part of the communion of all the saints in the koinonia of Christ. It is togetherness in love, a koinonia - a place where the Eucharist makes it possible for a Christian to be united with Jesus (Okonkwo 2010:94-95). The sacraments are a ritual event expressing the connections of the embodied finite human to the un-bodied infinite God. The sacraments are the means made available to people for communication with the Divine. And surely this communication is initiated by the Divine (O'Gorman 2016:433). The communion around the Eucharist is not fenced or parochial, as God's transcendence cannot be limited because of his omnipotence and omnipresence. Trying to fence off communion at the Lord's table should not be a matter of who is excluded, but rather ourselves who are included (Keyser \& Laubscher 2016:103). The same notion is carried by Ford (1999):

There is a sharp note of exclusion, but it is one that follows from the inclusiveness. The excluded are those who cannot bear God's generosity and will not imitate it. (p. 269)

The Eucharist is the Lord's table, where meals 'become celebrations, where conversation builds community, where enemies become friends, where Jesus is known in the breaking of bread' (De Gruchy 2016:63). Barring people from this table because of their sexual orientation is denying them the opportunity to commune with God their Creator. Rather, we should follow the apostolic assertion:

Everyone ought to examine themselves before they eat of the bread and drink from the cup. For those who eat and drink without discerning the body of Christ eat and drink judgment on themselves. (1 Cor 11:28-29)

Initiatives and intentions to exclude people from the sacraments and from opportunities for fellowshipping with God, based on their gender orientation, disregarding that they are people loved by God, is a sign of theological insecurity. 
Exclusion is perpetrated by discomfort with anything that blurs accepted boundaries, or anything that unsettles our cultural maps. We exclude because we want to be at the centre alone, in order to control people's sexuality.

This is highlighted by Volf (1996:77); exclusion goes hand in hand with a whole array of emotional responses to the other. Exclusion of homosexual people can be a result of hatred, indifference or intended dehumanisation.

Church membership is expressed through the sacraments incorporation (baptism) and liturgy (ongoing confession through the Eucharist). Many gay people confess to being born in this ecclesial communion through a covenant sealed by baptism, and/or they are continuing to actualise their belonging through liturgical confession of faith in Christ through participation in the Eucharist. The theological question here is who has the right or the authority to disqualify gay people from participating in baptism and the Eucharist, citing their sexual orientation as the reason? Is there anyone who can claim that authority to authenticate or disqualify a 'divergent' based on sexuality?

One of the church's privileges and joys is open membership. Christians are justified sinners (Rm 5:1-2) - sinners justified by faith, and God sees them as non-guilty based on their confession that they are sinners and their acceptance of Jesus into their lives for the forgiveness of their sins. If God is not a respecter of any person (Acts 10:34 KJV), can he be limited as to who he accepts or disqualifies from his koinonia? This is in line with the African communalistic value of human solidarity that sees all humanity as descending from a common source (Okonkwo 2010:96).

The Ethiopian eunuch in Acts 8 probably belonged to a sexual minority of the time, but upon being convicted that Jesus was the Messiah, he exclaimed and pleaded: 'Look, here is water. What can stand in the way of my being baptized?' And he gave orders to stop the chariot. Then both Philip and the eunuch went down into the water, and Philip baptised him (Ac 8:36-38). After the dialogue between the two, conviction and conversion followed. This encounter illustrates the need for dialogue with homosexual people.

Two people of the same gender can fall in love and request that their union be blessed by God through the church. According to South African law (Civil Union Act), their marital union is recognised and can be legalised. The church is struggling with solemnisation of this type of union. Traditionally and ecclesiastically, marriage is between two people of two different genders - male and female. Now the post-modern or post-Christian era conflicts with this longstanding tradition. How should the church respond? Should marriage be interpreted from the covenant theological perspective, where love reigns supreme? The fundamental matter here is that if two people of the same gender are deeply committed to each other and are deeply in love, can they not enter the everlasting covenantal relationship of marriage? This calls for some studious dialogue between the church and homosexual people.

If the church is the company of the redeemed and a platform on which the love of Christ is proclaimed, does she possess the exousia [authority, right, latitude] to deny somebody ordination into the ministry? If the church is the pillar of aletheia [truth], which is intertwined with agape [love], should her ordination of people be limited to certain people because of their sexual orientation? Dialogue is needed here to combine truth and love. The two must be balanced. The tendency among religious people is to articulate the right things but to neglect to live considering those truths (Sosler 2019:74). The time is ripe to revisit Jesus' emphasis on love and friendship - a chant popularised by the monks of Taizé Abbey: Ubi caritas et amor, Deus ibi est [Wherever compassion and love are present, there God is found]. In the same spirit, Vardy (1997) says:

If genuine, deep and committed love is possible between males and between females, then there seems no moral reason why this love should not be expressed sexually if the circumstances as well as the depth and commitment of the relationship warrants this. (pp. 219-220)

This scenario calls for a dialogue between the church and homosexual people - not for converting or convicting each other but to gain understanding and analyse how to walk together in the light.

\section{Dialogue partners: Church, community and same-sex partners}

Generally, the church and South African communities are broadly homophobic. Ecclesial discussions regarding same-sex relationships revolve around theological ethics. Traditionalists are deeply hostile, and argue from a cultural point of view. Religion and culture collaborate to oppose homosexuality from all societal angles. Kaoma (2016) correctly points out that:

Religious leaders not only reject the notion that homosexuality is a human rights issue, but also appeal to their religious convictions which prohibit same-gender relationships. It is within this sociopolitical and religious climate that the contestation of sexual diversity occurs. (pp. 22-23)

Culture and religion empower politics in order to dispute and nullify the reality of homosexuality. The arguments in these three spaces are so robust that consequently homosexual people become outcasts of the community. In theology, discussions were necessitated by discursive explosions of the practice, and the ethicists (Wells, Quash \& Eklund 2017) argue the approaches from universal (ethics for anyone), subversive (ethics for the excluded) and ecclesial (ethics for the church) points to try to balance description and critique, construction and analysis of issues such as homosexuality. However, throughout their work, they demonstrate that their thesis is not designed as a reductionist, watertight theory that diminishes the diversity and vitality of conversation 
across the discipline (2017:ix). It is difficult to dialogue issues in compartments. Comprehensive and eclectic approaches are ideal. These approaches engage all partners - perpetrators and victims, supporters and opponents and so on.

Dialogue is a tool for the church to address ethical issues perceived as hot buttons by the modern world.

Dialogue enables theology to take up the challenge of contributing towards shaping common life. It makes theology meaningful and relevant and enhances it to contribute towards social, political and economic empowerment. In dialoguing with the homophobic community, theology through dialogue journeys out of a continuous hermeneutic circle spanning the biblical text, dogmatic traditions and the present, ever-changing historical context (Cochrane 1999:52-63). This means that in dialogue, all perspectives, aspects and views should be listened to. The church as a dialogue partner, not a supremacist, should be attuned to a diversity of views. Attuning naturally leads to analysis, which ought to inaugurate the dynamic of applying (Grenz 1997:19). Homophobia is largely exacerbated by a lack of active listening by culturalists and religionists.

For centuries, the church occupied higher ground on moral issues, and with a supremacist attitude, vocally exerted authority over the issues of life, especially in matters of ethics. Life has taken a turn; now is the time for theology to constantly challenge the signs of the times (Villa-Vicencio 1992:41). Theologians are the 'cartographers of changing contexts' (Ackermann 1996:49). This means that they interpret the landscape of the present.

The replacement of condemnation with acceptance is not an easy path. Theological views on homosexuality have a proclivity towards non-acceptance; hence, symbiosis and synergy cannot easily be expected. In the meantime, change is inevitable. Homosexuality is in the pews, streets and marketplace. This is a new context that demands 'theology to adapt and to develop new methods and approaches when engaging with a democratic public sphere' (Kusmierz 2016:163).

It has been demonstrated above that although communities are homophobic, the literature shows that same-sex relationships are part of African history. Lesbian, gay, bisexual and transgender sexuality has existed as long as there has been human life on Earth (Wells 2016:124). Yet, the voices of criticism and opposition regarding the un-Africanness of homosexuality are vociferous and audible. The same sentiment is expressed by Hoad (2007:24): Beyond the 'assertion' and 'counterassertion' of the existence of homosexuality in Africa is how these arguments are used by opposing voices to justify their positions. The gospel presentation by colonialists not only labelled the cultural practices central to the social order of native persons as demonic and barbaric but also the people who practised them as of lesser intelligence and incapable of apprehending reality correctly (Turpin 2017:409).

This scenario and atmosphere create possibilities for dialogue, 'for silence and secrecy are a shelter of power, anchoring its prohibitions, but they also loosen its holds and provide for relatively obscure areas of tolerance' (Foucault 1990:101). Because theology is practised within communities, and communities are the communia of homosexual people, dialogue is a platform on which experiences can be articulated, understood and accounted for. The atmosphere must be free of judgement, resistance, bigotry or any form of inhibition.

Gay imperialism, race normativity, political protest and/or racism should not be allowed to reign on platform of dialogue:

Unless we learn to listen from 'voices outside' our heteronormative religious institutions, we risk ignoring the plight of sexual minorities in African biblical scholarship and interpretation. (Kaoma 2015:19)

Communities are, therefore, the legitimate locales where resistance against all forms of oppression can safely take place. Communities are spaces of coalitional inclinations, which is the space that is 'found within many multiplying minoritised groups' (Bakshi, Jivraj \& Posocco 2016:111), where sociopolitical discourses against social injustices can safely take place. This does not mean that there should be no conscious acknowledgement of dissimilarities. Homosexuality in South Africa is a very specific historically and socioculturally entrenched knowledge, therefore diversely and loosely understood. It is vital to acknowledge that:

When it is desirable that different sections of society engage in dialogue, there should also be a deep consciousness of the dissimilarity and the different forms of various sexual cultures. (Wekker 2016:121)

The church, community and homosexual people should contribute to alleviating social stigma and homophobia by engaging each other dialogically. Paulo Freire (1996:50) wrote these words of wisdom: 'Dialogue imposes itself as the way by which people achieve significance as human beings. Dialogue is thus an existential necessity'. The deepest act of dehumanisation, of treating people as things, is to strip them of the opportunity to dialogue (Haddad 2015:71). Freire continues in the same vein that anti-dialogical action is the antithesis of liberating praxis (1996:119-148) and needs to be replaced with dialogical action, for dialogue as the encounter among people is a fundamental precondition for their humanisation (1996:118). After all, 'the history of Africa is the story of ubuntu, solidarity, life-giving dialogue and hope' (Kaoma 2016:27).

Silence in times of calamity is as good as death. For public awareness to improve, there needs to be a more informed dialogue that will usher in better understanding. Leaving 
homophobia unaddressed does not help to bring it to an end. 'Realities of war and conflict need to be faced not avoided' (Tombs 2014:162). There is no doubt about the need for proactive engagement, for as Dreyer says, '[e]ngagement and personal involvement are the only way' (2008:1244). The church, community and homosexual people should together identify a doable step in research that will develop models of dialogue that are suited for different religious groups in dealing with homophobia. 'We must make allowance for the complex and unstable process whereby discourse can be both an instrument and an effect of power ...' (Foucault 1990:101).

\section{Healing of homophobia: All dialogue partners need it}

All three partners - community, church and homosexual people - need to embark on the road of healing. Communities need to practise love, the church needs to promote faith and gay people need to enhance hope that the other partners will finally understand each other. This is an eschatological journey; therefore, all dialogists should embark on it.

All dialogue partners should seek self-understanding, enhancing the principle of fraternity, solidarity or comradeship - community of equality and liberty (Tillich 1970:62). Homosexual people are to understand that all people are human beings. There are only people, all created alike in the image of God, though fallen into a state of sexual crisis and confusion. Self-condemnation is not the alternative route in the course of life. On the contrary, communities must accept that all people are sexual beings. Human sexuality is closely attached to human personality. All people have a sexual orientation. Homosexuality is a human reality. The ecclesiastical community should argue their stance on the theological dictum that all people are sinners, indeed, sexual sinners. The total depravity of humanity asserts that humanity has been tainted and twisted by sin, and that includes our sexuality. The human tendency is to deviate from God's perfect intended sexuality.

Nobody has ever been sexually sinless. This automatically disqualifies any person to judge, dismiss or exclude any person perceived to be sexually deviant. If humanity, like all creation, is eschatologically reconstructed - a continuous act of God - then who has the latitude to dismiss a sexually deviant person?

Love should replace homophobia, for love is an analytical and ethical ontology that seeks to encounter the reality. The encounter is inevitable as the dialogists convene to find the power of life. In this kind of attempt, love drives towards the unity of the separated. It drives the strangers (enemies) to enter a communion. Love seals the relationship of a union of strangers and the reunion of the estranged. 'Love manifests its greatest power there where it overcomes the greatest separation' (Tillich 1970:25).
The language of faith, hope and love enables us to understand others from a different orientation either culturally or sexually - either those who despise us or those we ourselves despise. De Gruchy (2016) speaks of this language as:

$[N]$ ot the language of facts and figures, of molecules and pigments, of law and the courthouse, but that of embracing the stranger without which we would lose our humanity and be incapable of expressing our gratitude and love to God. (p. 23)

The church is a community of love and inclusion. Jesus opened participation in this community to all those who choose to be part of it. The church, like Jesus, should love people in all their real social aspects. The church is expected to stand in sharp contrast to the relatively rigid social boundaries created by culture. She has to refuse the boundaries between being righteous and outcast, male and female, rich and poor, Jew and Gentile, heterosexual and homosexual.

\section{Conclusion}

Homosexuality is an irreversible reality in South African societies. It is in the church, but in a subliminal way.

It has been criticised both by the church and traditionalists alike. The literature demonstrates that same-sex relations are not a new phenomenon. Homophobia manifests itself in devious and inhuman ways. This essay calls for dialogue between communities, churches and homosexual people - to talk in order to alleviate misunderstanding about each other. Dialogue is the key to understanding the other side, and it is through dialogue that strangers can meet and find each other. Exclusion from the sacraments and ordination is not a solution; it is merely denying people loved by God an opportunity to meet their God in a loving and embracing manner. A journey towards ethical acceptance of homosexuals should include engaging in dialogue towards alleviating homophobia.

\section{Acknowledgements}

Through a review of literature from church history, missiology, African studies and systematic theology, homophobia is traced as an historical tension that was exacerbated by colonial Christianity - in partnership with some African cultural convictions, despite the historical evidence that homosexuality was embedded in some African cultures. Some biblical texts are used to either condemn or condone homosexuality. These tensions are debated theologically and historically, and it is recommended that the church should dialogue with homosexual people, embrace them and try to understand them, instead of nullifying their religious confessions and excluding them from the liturgies and sacraments. This dialogue is intended to reach an understanding and see how to minimise the condemnation of our fellow human beings who are carriers of the imago Dei. 


\section{Competing interests}

The author has declared that no competing interests exist.

\section{Author's contributions}

I declare that I am the sole author of this research article.

\section{Funding information}

This research received no specific grant from any funding agency in the public, commercial or not-forprofit sectors.

\section{Data availability statement}

Data sharing is not applicable to this article as no new data were created or analysed in this study.

\section{Disclaimer}

The views and opinions expressed in this article are those of the author and do not necessarily reflect the official policy or position of any affiliated agency of the author.

\section{References}

Ackermann, D., 1996, 'Engaging freedom: A contextual feminist theology of praxis', Journal of Theology for Southern Africa 94 (March), 32-49.

Bakshi, S., Jivraj, S. \& Posocco, S., 2016, Decolonizing sexualities: Transnational perspectives and critical interventions, Counterpress, Oxford.

Bernadine, E., 2014, 'The idea that African homosexuality was a colonial import is a myth', The Guardian, 08 March 2014, pp. 7-8.

Bolich, G.G., 2007, Transgender history \& geography: Crossdressing in context, vol. 3 Psyche's Press.

'Botswana chiefs: "Homosexuality has always been here" erasing 76 crimes. The human toll of 70-plus countries' anti-gay laws', The Struggle to repeal them, July 26, 2013, viewed from https://76crimes.com/2013/07/26/botswana/

Bradshaw, T., 1992, The olive branch: An evangelical Anglican doctrine of the church, Paternoster Press, Carlisle.

Butler, A. \& Astbury, G., 2005, 'Over the rainbow: Recommendations for service provision as voiced by post-apartheid South African gay and lesbian youth', Journal of Child and Youth Care Work 19, 126-136.

Clarke, M., 2011, 'Growing up gay in black America: An exploration of the coming out process of Queer African American Youth', Dissertation submitted in partial fulfill of the requirements for the degree of Doctor of Philosophy in Marriage and Family Therapy, Syracuse University, December 2011, University of Southern Mississippi, Syracuse.

Cochrane, J.R., 1999, Circles of dignity: Community wisdom and theological reflection, Augsburg Fortress, Minneapolis, MN.

Cook, D., 1990, The moral maze: A way of exploring Christian ethics, SPCK, London.

Crompton, L., 2003, Homosexuality and civilisation, The Belknap Press of Harvard University, Cambridge, MA.

De Gruchy, J., 2016, Without apology: Faith, hope and love in a time of doubt, despair and violence, The Methodist Publishing House, Woodstock, GA.

Dreyer, Y., 2008, 'A pastoral response to the unhealed wound of gays exacerbated by indecision and inarticulacy', HTS/Theological Studies 64(3), 1235-1254. by indecision and inarticulacy', $H$ TS
https://doi.org/10.4102/hts.v64i3.71

Dube, M.W., 2004, 'Go therefore and make disciples of all nations (Matt 28:19A). A postcolonial perspective on Biblical Criticism and pedagogy', in F.F. Segovia \& M.A. Tolbert (eds.), Teaching the Bible: The discourses and politics of Biblical pedagogy, pp. 224-246, Wipf and Stock, Eugene, OR.

Epprecht, M., 2003, Hungochani (2 ed): The history of a dissident sexuality in Southern Africa, McGill-Queen's University Press, Montreal.

Ford, D., 1999, Self and salvation: Being transformed, Cambridge University Press, Cambridge.

Foucault, M., 1990, The will to knowledge: The history of sexuality, vol. 1, transl R. Hurley, Penguin Books, London.

Freire, P., 1996, Pedagogy of the oppressed, Rev edn., Penguin, London.

Ganzevoort, R., Van der Lan, M. \& Olsman, E., 2011, 'Growing up gay and religious: Conflict, dialogue, and religious identity strategies', Mental Health, Religion, and Culture 14(3), 209-222. https://doi.org/10.1080/13674670903452132
Garner, H. \& Worsnip, M., 2001, 'Oil and water: The impossibility of gay and lesbian identity within the church', in A. Nolan, M.T. Speckman \& L.T. Kaufmann (eds.), Towards an agenda for contextual theology: Essays in Honour of Albert Nolan, Towards an agenda for contextual theology: Essays in
pp. 205-230, Cluster Publications, Pietermaritzburg.

Grenz, S.J., 1997, The moral quest: Foundations of Christian ethics, InterVarsity Press, Downers Grove, IL.

Haddad, B., 2015, Keeping body and soul together: Reflections by Steve de Gruchy on theology and development, Cluster Publications, Pietermaritzburg.

Hoad, N., 2007, African intimacies, University of Minnesota Press, Minneapolis, MN. Johnson, A.F., 1979, Romans: The freedom letter, vol. 1, Moody Press, Chicago, IL.

Kaoma, K., 2015, 'Beyond Adam and Eve: Jesus, sexual minorities and sexual politics in the church in Africa', Journal of Theology for Southern Africa 153 (November), 7-28.

Kaoma, K., 2016, “'I say, we must talk, talk mama!”: Introducing African voices on religion, Ubuntu and sexual diversity', Journal of Theology for Southern Africa 155 (July), 6-27.

Keyser, N. \& Laubscher, M., 2016, 'Envisioning economic justice from a Eucharistic Foundation', Journal of Theology for Southern Africa 156 (November), 90-104.

Kuloba, R.W., 2016, “Homosexuality is Unafrican and unbiblical”: Examining the ideological motivations to homophobia in sub-Saharan Africa - The case study of Uganda', Journal of Theology for Southern Africa 154 (March), 6-27.

Kusmierz, K., 2016, Theology in transition: Public theologies in post-apartheid South Africa, LIT Verlang GmbH \& Co, KG Wien, Zurich.

Laird, J., 1998, 'Theorizing culture: Narrative ideas and practice principles', in M. McGoldrick (ed.), Re-visioning family therapy: Race, culture, and gender in clinical practice, pp. 20-36, Guilford Press, New York, NY.

Long, S., Brown, W. \& Cooper, G., 2003, More than a name: State-sponsored homophobid and its consequences in Southern Africa, Human Rights Watch, New York.

Mabvurira, V., Motsi, P.D., Masuka, T. \& Chigondo, E.E., 2012, 'The "politics" of sexual identities in Zimbabwe: A social work perspective?', International Journal of Humanities and Social Science 2(13), 218-223.

Msibi, T., 2012, “I' $m$ used to it now": Experiences of homophobia among queer youth in South African township schools', Gender and Education 24(5), 515-533. https://doi.org/10.1080/09540253.2011.645021

Murray, S.O. \& Roscoe, W., 2019, Boys-wives and female husbands, viewed 22 March 2020, from http://www.willsworld.org/africa.html.

Nel, M., 2019, 'Pentecostals, LGBTIQ+ people and the Bible: An alternative Pentecostal hermeneutical perspective', Stellenbosch Theological Journal 5(3), 515-540. https://doi.org/10.17570/stj.2019.v5n3.a24

O'Gorman, R.T., 2016, 'Imagination embodied: The sacraments reappropriated', Religious Education 111(4), 430-446. https://doi.org/10.1080/00344087.2016.1185768

Okonkwo, I., 2010, 'The sacrament of the Eucharist (as Koinonia) and African sense of communalism: Towards a synthesis', Journal of Theology for Southern Africa 137 (July), 88-103.

Progressive prudes. A survey of attitudes towards homosexuality \& gender non-conformity in South Africa, 2016, The Other Foundation, viewed 5 April 2020 from http://theotherfoundation.org/progressive-prudes/.

Rodriguez, E.M., 2009, 'At the intersection of church and gay: A review of the psychological research on gay and lesbian Christians', Journal of Homosexuality 57(1), 5-38. https://doi.org/10.1080/00918360903445806

Sosler, A., 2019, 'Reason, love, and morality: The limits of reason in Kohlberg and the importance of love in Augustine and Smith', Religious Education 114(1), 69-81. https://doi.org/10.1080/00344087.2018.1492290

Tillich, P., 1970, Love, power, and justice: Ontological analyses and ethical application, Oxford University Press, New York, NY.

Tombs, D., 2014, 'Silent no more: Sexual violence in conflict as a challenge to the worldwide church', Acta Theologica 34(2), 147-165. https://doi.org/10.4314/ actat.v34i29

Turpin, K., 2017, 'Christian education, white supremacy, and humility in formational agendas', Religious Education 112(4), 407-418. https://doi.org/10.1080/0034408 7.2017.1300843

Vardy, P., 1997, The puzzle of sex, Fount Paperbacks, HarperCollins Publishers, London.

Villa-Vicencio, C., 1992, A theology of reconstruction: Nation - Building and human rights, Cambridge Studies in Ideology and Religion, Cambridge University Press, Cambridge.

Volf, M., 1996, Exclusion \& embrace: A theological exploration of identity, otherness, and reconciliation, Abingdon Press, Nashville, TN.

Wekker, G., 2016, White innocence: Paradoxes of colonialism and race, Duke University Press, Durham, NC.

Wells, S., 2016, How then shall we live? Christian engagement with contemporary issues, Canterbury Press, London.

Wells, S., Quash, B. \& Eklund, R., 2017, Introducing Christian ethics, 2nd edn., Wiley Blackwell \& Sons, Oxford.

Wenham, G.J., 1979, The book of leviticus, Hodder and Stoughton, London.

Wilhelm, A.D., 2004, Tritiya-Prakriti: People of the third sex - Understanding homosexuality, transgender identity, and intersex conditions through Hinduism, Xlibris Corporation, Philadelphia, PA.

West, G., 2017, 'What would Jesus do? Towards an inclusive ethic', in M.R. Gunda \& J.Naughton (eds.), On sexuality and scripture: Essays, bible studies and personal reflections by the Chicago consultation, pp. 19-25, The Ujamaa Centre, and Their Friends, Cluster Publications, Pietermaritzburg.

Zabus, C. \& Coad, D. (eds.), 2013, Transgender experience: Place, ethnicity, and visibility, Routledge, New York, NY. 